\title{
Evaluation of different methods of turmeric (Curcuma longa L.) plantation
}

\author{
AJAIB SINGH* AND SUMANJIT KAUR \\ Krishi Vigyan Kendra, Bahowal, HOSHIARPUR (PUNJAB) INDIA (Email : as.ajaib82@gmail.com)
}

\begin{abstract}
A study on different methods of turmeric (Curcuma longa L.) planting was carried out at farmers' field of district Hoshiarpur to evaluate the growth and yield of turmeric. The mean length of turmeric rhizomes for $\mathrm{T}_{1}$ (planting of turmeric manually at $30 \mathrm{~cm} \times 20 \mathrm{~cm}$ spacing), $\mathrm{T}_{2}$ (planting of turmeric manually at $45 \mathrm{~cm} \times 15 \mathrm{~cm}$ spacing) and $\mathrm{T}_{3}$ (planting of turmeric with semi-automatic potato planter at a spacing of $60 \mathrm{~cm} \times 15 \mathrm{~cm}$ ) after uprooting was $7.85 \mathrm{~cm}, 7.91 \mathrm{~cm}$ and $8.20 \mathrm{~cm}$, respectively while the mean diameter of turmeric rhizomes for $\mathrm{T}_{1}$, $\mathrm{T}_{2}$ and $\mathrm{T}_{3}$ after uprooting was $3.05 \mathrm{~cm}, 2.64 \mathrm{~cm}$ and $3.45 \mathrm{~cm}$, respectively. The number of rhizomes per $\mathrm{kg}$ for $\mathrm{T}_{1}, \mathrm{~T}_{2}$ and $\mathrm{T}_{3}$ were 34,30 and 24 , respectively. The yield of turmeric rhizome was highest (130.0 q/acre) in $\mathrm{T}_{3}$ which was 17.65 per cent and 8.33 per cent more as compared to $\mathrm{T}_{2}$ and $\mathrm{T}_{1}$, respectively because the rhizomes were grown on ridges and the overall size of rhizomes was bigger.
\end{abstract}

Key Words : Turmeric, Growth, Planting method, Yield

View Point Article : Singh, Ajaib and Kaur, Sumanjit (2015). Evaluation of different methods of turmeric (Curcuma longa L.) plantation. Internat. J. agric. Sci., 11 (1): 201-203.

Article History : Received : 29.03.2014; Accepted : 27.12.2014

\footnotetext{
* Author for correspondence
} 